\title{
Effect of a Heating System Using a Ground Source Geothermal Heat Pump on Production Performance, Energy-Saving and Housing Environment of Pigs
}

\author{
Hong Seok Mun ${ }^{1}$, Muhammad Ammar Dilawar ${ }^{1}{ }^{\mathbb{D}}$, Myeong Gil Jeong ${ }^{1}$, \\ Dhanushka Rathnayake ${ }^{1}{ }^{\mathbb{D}}$, Jun Sung Won ${ }^{1}$, Kwang Woo Park ${ }^{2}$, Sang Ro Lee ${ }^{2}$, Sang Bum Ryu ${ }^{3}$ \\ and Chul Ju Yang 1,* \\ 1 Department of Animal Science and Technology, Animal Nutrition and Feed Science Laboratory, \\ Sunchon National University, Suncheon 57922, Korea; mhs88828@nate.com (H.S.M.); \\ ammar_dilawar@yahoo.com (M.A.D.); wjdaudrlf13@naver.com (M.G.J.); dhanus871@gmail.com (D.R.); \\ jongmin2301@naver.com (J.S.W.) \\ 2 WP Co., Ltd., Suncheon 58023, Korea; pkw9872@naver.com (K.W.P.); skylife37@naver.com (S.R.L.) \\ 3 Department of Mechanical Convergence Engineering, Hanyang University, Seoul 04763, Korea; \\ fbvod@hanmail.net \\ * Correspondence: yangcj@scnu.ac.kr; Tel.: +82-61-750-3235
}

Received: 14 October 2020; Accepted: 6 November 2020; Published: 9 November 2020

Simple Summary: A geothermal heat pump (GHP) was installed in a pig house, and production performance, housing environment, energy efficiency, noxious and carbon dioxide $\left(\mathrm{CO}_{2}\right)$ gas emissions, and economics were compared between GHP and the control (conventional heating). The $\mathrm{CO}_{2}$ gas emission, usage, and cost of electricity were reduced in the GHP-installed pig house. The GHP also maintained the inside temperature of the pig house more effectively. Furthermore, the concentration of noxious gas $\left(\mathrm{NH}_{3}\right)$ was also lower during the growing and finishing phase in the GHP-installed pig house. Therefore, the results indicate that the GHP system can be used for sustainable pig production and food security as a climate-friendly renewable energy source for livestock.

Abstract: This study examined the effects of a heating system using a ground source geothermal heat pump (GHP). A GHP was installed in a pig house, and a comparative analysis was performed between the GHP and the control (conventional heating system) in terms of the production performance, housing environment, noxious gas emissions, electricity consumption, and economics. The geothermal system performance index, such as the coefficient of performance (COP), inlet, and outlet temperature, were also evaluated. The outflow temperature during each period (weaning, growing, and finishing) was significantly higher than the inflow temperature in all three components of the GHP system. Similarly, the average internal temperature of the GHP-connected pig house was increased $(p<0.05)$ during each period. The carbon dioxide $\left(\mathrm{CO}_{2}\right)$ concentration, electricity usage, and cost of electricity during the 16-week experimental period were reduced significantly in the GHP system relative to the control. The concentrations of ammonia $\left(\mathrm{NH}_{3}\right)$ during the growing and finishing period and the concentrations of formaldehyde during the weaning phase were also lower in the GHP-installed pig house $(p<0.05)$. These results indicate that the GHP system can be used as an environmentally friendly renewable energy source in pig houses for sustainable pig production without harming the growth performance.

Keywords: geothermal heat pump; energy consumption; sustainable; coefficient of performance; pig house; noxious gas emission 


\section{Introduction}

For pigs, efficient production performance is affected by the temperature, humidity, heating system, and environment of the pig house. The temperature of the pig house is the most critical parameter in the weaning phase, which must be around $26^{\circ} \mathrm{C}$. A significant part of the total cost associated with swine farming is to maintain the optimal temperature for piglets [1]. In Korea, the outside temperature is below the freezing point during winter. As a result, pigs are exposed to cold stress; hence, heating the pig house is essential.

Air quality is also one of the important variables that include humidity, dust, and harmful gaseous metabolites. Pig farming in Korea has increased greatly; however, with the increasing production, pig farms have become an active contributor to ammonia $\left(\mathrm{NH}_{3}\right)$ and carbon dioxide $\left(\mathrm{CO}_{2}\right)$ emissions into the environment [2]. Some authors [3,4] have reported that the housing environment plays a major role in the amount of $\mathrm{NH}_{3}$ emission from animal farm facilities. The main housing factors for $\mathrm{NH}_{3}$ emission are the floor type (concrete slats or plastic slats), a bedded system, and a separate area for feeding and resting [5]. $\mathrm{NH}_{3}$ is a notorious gas with adverse effects on pig production, welfare, and health. Moreover, $\mathrm{NH}_{3}$ released into the atmosphere is the main cause of environmental pollution associated with agriculture and livestock, constituting $95 \%$ of anthropogenic emissions [6]. $\mathrm{CO}_{2}$ is the most common greenhouse gas, and $32 \%$ of this gas is emitted as a result of electricity use for heating [7]. During the cold season, the concentration of $\mathrm{CO}_{2}$ increases due to the heating of the swine house using fossil fuels. Hence, there is a strong need in the pork production industry for the utilization of energy resources that can decrease the emissions of harmful gases and are safe for the health of workers and pigs, environmentally friendly, and cost-effective [8].

Energy shortage is a crucial problem throughout the world, and the pressure is increasing on the supply of energy as its consumption is increasing every year. In global energy consumption, more attention is being paid to the use of renewable energy sources [9]. These renewable sources make a significant difference in reducing noxious gas emission, controlling pollution, and enhancing sustainable development [10]. Furthermore, fluctuations in energy prices and regulations to decrease harmful gases have become major challenges to the pig industry for sustainable production. There is a need for interventions on animal housing aimed at decreasing the energy demands of livestock farms and enhancing energy efficiency by introducing renewable energy sources [11]. A geothermal heat pump (GHP) is an efficient and innovative energy technology that utilizes the groundwater or earth's natural heat storage capacity for cooling and heating. A GHP can supply at least three units of geothermal energy while consuming only one unit of electricity [12]. During the heating mode, a 30-70\% reduction in energy consumption can be achieved. GHP improves the quality of the internal air of the animal house by supplying fresh air, and the system does not produce combustion pollutants directly $[8,13]$. Moreover, a GHP is considered to be the most energy-efficient, environmentally safe, and economically feasible of all of the heating options [14].

Geologically, South Korea has a huge reservoir of geothermal energy resources (GER). Lee et al. [15] reported that if $2 \%$ of the GER from the earth surface to a depth of $5 \mathrm{~km}$ deep is used, the energy obtained would be equal to 200 times the primary energy consumption in South Korea annually. In particular, for livestock, GER can be used at depths of up to 100 to $500 \mathrm{~m}$ to operate a GHP depending on the heat load of the animal house [16]. GHPs have been used globally as a climate-friendly and renewable energy source not only for industrial applications but also for energy production in agricultural and livestock farms for heating and cooling [17,18]. Moreover, equipping a pig house with a heating system using GER will be more economical, effective, and environmentally clean. Despite these potential advantages, few studies have examined the impact of a heating system using a GHP system on the housing environment and production performance of pigs [11]. Therefore, a study was conducted to examine the effects of a GHP system on the production parameters and housing environment of pigs during winter. 


\section{Materials and Methods}

\subsection{Animal Care}

This experimental trial was conducted at the study farm of Sunchon National University, Suncheon, South Korea. The experimental procedures and management and care of pigs were approved and reviewed by the Institutional Animal Care and Use Committee (IACUC), Sunchon National University (SCNU IACUC 2019-12).

\subsection{Animals and Housing}

The performance of the GHP was evaluated in winter from 20 December 2019 to 17 January 2020 (four weeks for the weaning period), 18 January to 28 February 2020 (six weeks for the growing period), and 29 February to 10 April 2020 (six weeks for the finishing period). The pigs (Landrace $\times$ Duroc $\times$ Yorkshire) were reared in two separate rooms $(300 \mathrm{~cm}$ wide $\times 820 \mathrm{~cm}$ long), which were further divided into ten individual pens (Figure 1a). Out of the two east-facing identical environmentally controlled rooms, the first room was connected to the GHP system (Figure 2), while the other room was installed with a conventional electric heating system (heat lamps) and was used as a control (Figure 1b). The heating lamp $(600 \mathrm{~W})$ was placed on the top of each pen, and their height was adjusted according to the age of the pigs.

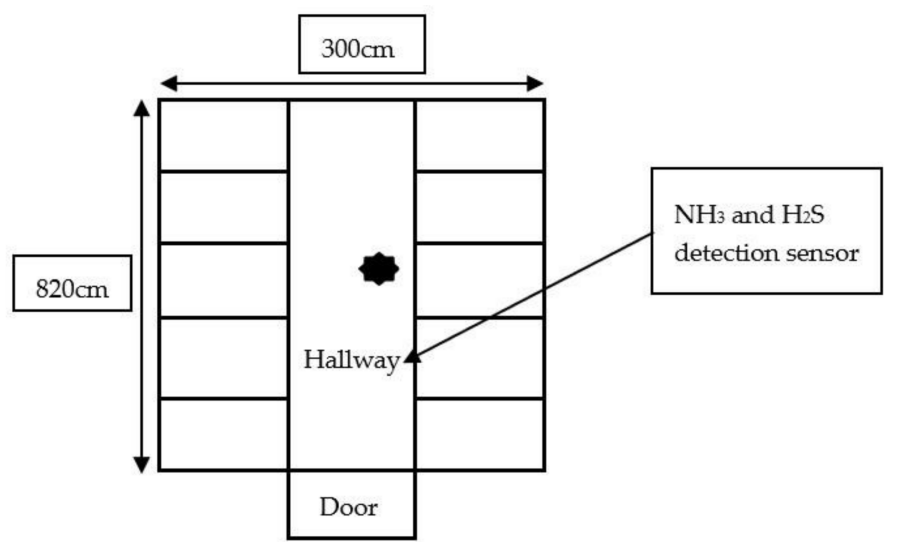

(a)

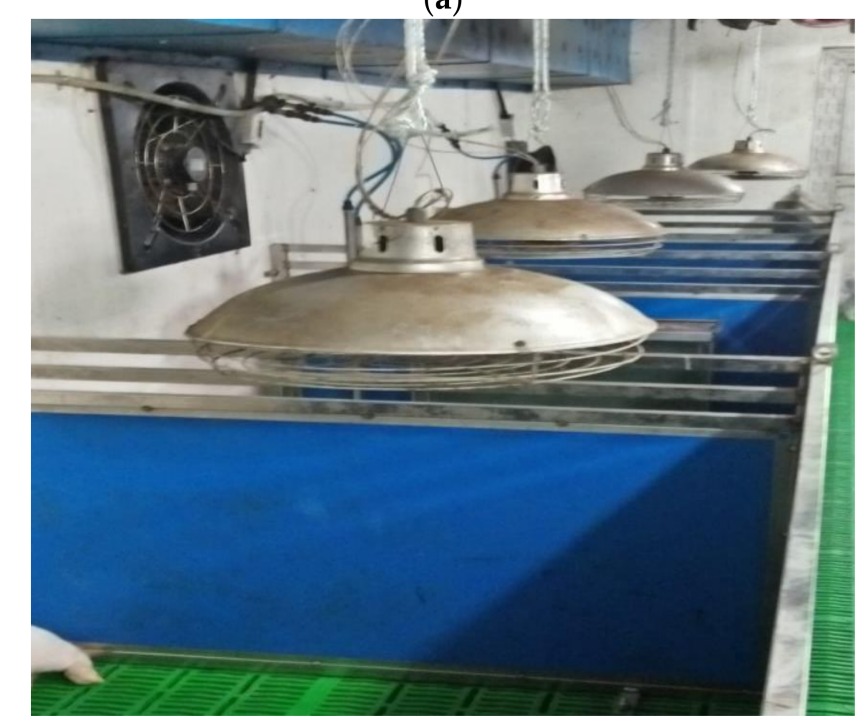

(b)

Figure 1. (a) Schematic diagram of the pig house with the location of sensors for the detection of noxious gases $\left(\mathrm{NH}_{3}\right.$ and $\left.\mathrm{H}_{2} \mathrm{~S}\right)$; (b) inside view of control pig house with electric heating lamps. 


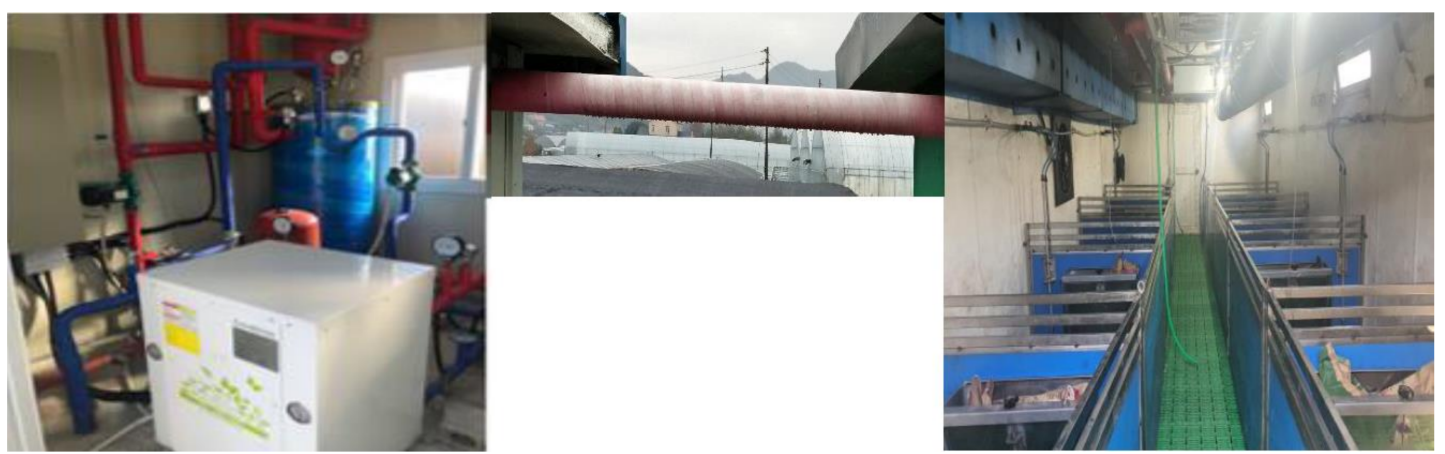

Figure 2. Schematic diagram of the geothermal heat pump (GHP) system for the pig house.

All pigs were reared in a slatted floor pig house and provided commercially available feed and water ad libitum. The ingredients and chemical composition of the experimental diets are shown in Table 1. The pig houses were well insulated to obtain the desired humidity and temperature during the study trial.

Table 1. Ingredients and chemical composition of the experimental diets.

\begin{tabular}{cccc}
\hline & $\begin{array}{c}\text { Weaning Pigs, 0-4 } \\
\text { Weeks }\end{array}$ & $\begin{array}{c}\text { Growing Pigs, } \\
\text { 4-10 Weeks }\end{array}$ & $\begin{array}{c}\text { Finishing Pigs, } \\
\text { 10-16 Weeks }\end{array}$ \\
\hline Yellow corn & Ingredients (\% as fed basis) & \\
Rice bran & 47.80 & 51.36 & 55.00 \\
Rapeseed oil & 14.00 & 7.00 & 8.00 \\
DDGS & - & 1.72 & 3.00 \\
Soybean meal & - & 6.00 & 6.00 \\
Limestone & 22.10 & 21.80 & 18.16 \\
Calcium phosphate & 0.70 & 0.84 & 1.00 \\
Salt & 0.70 & 0.10 & 0.20 \\
Vit-min premix 2 & 0.15 & 0.30 & 0.30 \\
Animal fat & 0.50 & 0.45 & 0.20 \\
Molasses & 7.00 & 6.78 & 4.76 \\
Amino acid additive & 2.00 & 2.50 & 2.50 \\
& 5.05 & 1.15 & 0.88 \\
\hline ME ${ }^{3}$ (kcal/kg) & Chemical composition $(\% \mathrm{DM})$ & \\
Crude protein & 3350.00 & 3265.00 & 3265.00 \\
Ca (\%) & 19.00 & 18.00 & 17.00 \\
Available P (\%) & 0.70 & 0.80 & 0.80 \\
Lysine (\%) & 0.44 & 0.34 & 0.34 \\
Methionine (\%) & 1.35 & 1.20 & 1.10 \\
(s) & 0.53 & 0.37 & 0.31 \\
\hline
\end{tabular}

${ }^{1}$ Distiller's dried grains with solubles. ${ }^{2}$ Vit-min premix provided following nutrients per kg of premix: vitamin A, $6000 \mathrm{IU}$; vitamin $\mathrm{D}_{3}, 800 \mathrm{IU}$; vitamin E, $20 \mathrm{IU}$; vitamin $\mathrm{K}_{3}, 2 \mathrm{mg}$; thiamin, $2 \mathrm{mg}$; riboflavin, $4 \mathrm{mg}$; vitamin $\mathrm{B}_{6}, 2 \mathrm{mg}$; vitamin $\mathrm{B}_{12}, 1 \mathrm{mg}$; pantothenic acid, $11 \mathrm{mg}$; niacin, $10 \mathrm{mg}$; biotin, $0.02 \mathrm{mg}$; $\mathrm{CU}$-copper sulfate, $21 \mathrm{mg}$; Fe-ferrous sulfate, $100 \mathrm{mg}$; $\mathrm{Zn}$ —zinc sulfate), $60 \mathrm{mg}$; $\mathrm{Mn}$-manganese sulfate, $90 \mathrm{mg}$; I—calcium iodate, $1.0 \mathrm{mg}$; $\mathrm{CO}$ —cobalt nitrate, $0.3 \mathrm{mg}$; Se-sodium selenite, $0.3 \mathrm{mg}$. ${ }^{3}$ Metabolizable energy.

\subsection{Description of the GHP System}

The GHP system consisted of a borehole exchanger (BHE, double U tube with a depth of $150 \mathrm{~m}$ ), heating pump unit (HPU), water circulating pumps, fan coil unit (FCU), and a thermal water tank (Figure 3). The water-to-water heat pump unit (Daesung, DHGW 5N-C4-02, Seoul, Republic of Korea) (Supplementary Figure S1) was installed and connected to the pig house using the method reported by Sebarchievici and Sarbu [19]. The energy consumption of the system was $4.93 \mathrm{~kW}$, with a cooling and heating capacity of 20.59 and $19.66 \mathrm{~kW}$, respectively. The water storage capacity of the thermal tank was approximately $260 \mathrm{~L}$ and attached to the heat pump to store water for the transfer of heat to the 
pig house through the FCU. The FCU can provide different wind speeds with temperatures ranging from 5 to $45^{\circ} \mathrm{C}$. The system was equipped with the following three circulating pumps: (1) to transfer groundwater to the heat pump (Model: PH-200M, Wilo pump, Ansan, South Korea, with a flow rate of $136 \mathrm{~L} / \mathrm{min}$ ), (2) to transfer water from the heat pump to the water tank (Model: PH-080M, Wilo pump, Ansan, South Korea, with a flow rate of $75 \mathrm{~L} / \mathrm{min}$ ), and (3) to transfer from the water tank to the pig house (Model: PB-600MA, Wilo pump, Ansan, South Korea, with a flow rate of $80 \mathrm{~L} / \mathrm{min}$ ). Detailed specifications of the geothermal heat pump are presented in Supplementary Table S1.

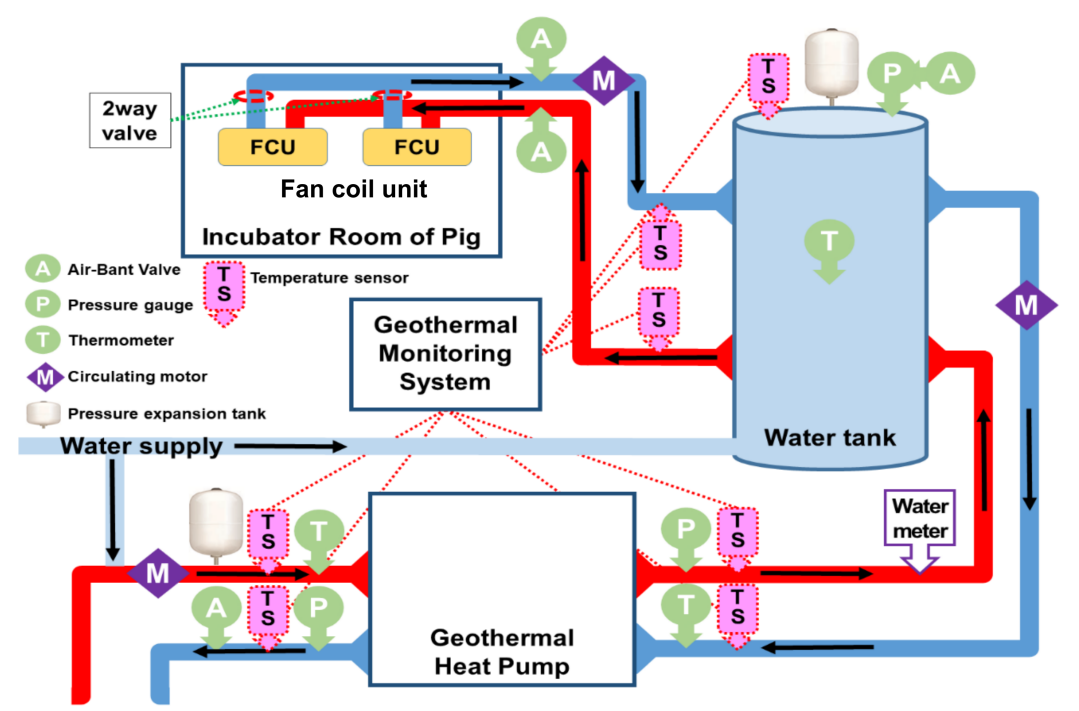

Figure 3. An overview of the ground source geothermal heat pump system.

The HPU consisted of a thermostatic expansion valve, a rolling piston compressor, and a copper tube in tube heat exchangers (evaporator, superheater, and condenser). The condenser can increase the temperature of air from $20^{\circ} \mathrm{C}$ to $55-60{ }^{\circ} \mathrm{C}$ and distribute it to the pig house through plastic ducts. The air temperature was adjusted in the heat pump by a regulator in response to changes in the pig house temperature. The air within the pig house was displaced by the incoming hot air, which was ventilated by exhaust fans. Detailed specifications of exhaust fans are presented in Supplementary Table S2. The ventilation rate was adjusted at $2 \mathrm{cfu} / \mathrm{unit}$ for weaning pigs, $3 \mathrm{cfu} /$ unit for growing pigs, and $7 \mathrm{cfu}$ for finishing pigs. The volumetric flow of air was $700 \mathrm{~m}^{3} / \mathrm{min}$ through the heat pump. Water flows across the tubes while a refrigerant flows inside the tubes in all heat exchangers. The environment friendly working fluid R-410A was used in the heat pump.

\subsection{Temperature and Coefficient of Performance (COP)}

The outside and inside temperature of the control and GHP-installed pig house was measured using temperature detection sensors with a range of -20 to $80^{\circ} \mathrm{C} \pm 0.2^{\circ} \mathrm{C}$ and linked with data loggers (CR10X Data Logger, Campbell Scientific, Edmonton, Canada) and integrated negative temperature coefficient thermistor as sensors. The temperature of the cold and hot water (outflow and inflow) of GHP, heating water tank (inflow and outflow), and water storage tank was measured by using a pipe temperature sensor (GPT-1000, Ginice, Korea), which contains a high-quality thermistor sensing element suitable for use in the range from -50 to $150{ }^{\circ} \mathrm{C}$.

The COP of the GHP was calculated using Equations (1) and (2) [8].

Heat absorbed $(\mathrm{kW})=\mathrm{M} \times \mathrm{Cp} \times \Delta \mathrm{T} \times 4.2 \div 3600$

$$
\mathrm{COP}=\frac{\text { Heat absorbed }(\mathrm{kW})+\text { Power consumption }(\mathrm{kW})}{\text { Power consumption }(\mathrm{kW})}
$$


where $\mathrm{M}=$ mass flow rate $\left(\mathrm{kgh}^{-1}\right), \mathrm{C}_{\mathrm{p}}=$ Specific heat $\left(\mathrm{Jkg}^{-1} \mathrm{~K}^{-1}\right)$, and $\Delta \mathrm{T}=$ inlet-outlet temperature difference $\left({ }^{\circ} \mathrm{C}\right)$.

\subsection{Electricity Consumption and $\mathrm{CO}_{2}$ Concentration}

The electricity consumption for heating the control and GHP-installed pig house was calculated every day by installing two separate smart energy electrical submeters for each house. The cost of electricity was calculated by multiplying the electricity consumption by the current electricity cost in South Korea $(1 \mathrm{kWh}$ electricity $=39.2$ Korean won $(K R W)$ and 39.2 Korean won $=0.033$ USD).

The emission of $\mathrm{CO}_{2}$ was calculated using the procedure reported by Islam et al. [8] for South Korea. They calculated the $\mathrm{CO}_{2}$ emissions as $\mathrm{kg} \mathrm{CO}_{2}$ equivalent, based on daily electricity consumption, where $1 \mathrm{kWh}=0.547 \mathrm{~kg} \mathrm{CO}_{2}$ emission equivalent.

\subsection{Ultrafine Dust $\left(P M_{2.5}\right)$ and Formaldehyde}

The ultrafine dust particulate matter $\left(\mathrm{PM}_{2.5}\right)$ and formaldehyde (FA) levels were determined using a smart sensor air quality meter (AR830A, Dongguan, China) (Supplementary Figure S3) with a range of $0-150 \mu \mathrm{g} / \mathrm{m}^{3}$ for $\mathrm{PM}_{2.5}$ and $0-5 \mathrm{ppm}$ for FA, respectively. The concentration of $\mathrm{PM}_{2.5}$ and FA was recorded daily at the same time by placing the sensor in the middle of the pig house.

\subsection{Ammonia $\left(\mathrm{NH}_{3}\right)$ and Hydrogen Sulfide $\left(\mathrm{H}_{2} \mathrm{~S}\right)$ Concentration}

The concentrations of harmful gases $\left(\mathrm{NH}_{3}\right.$ and $\left.\mathrm{H}_{2} \mathrm{~S}\right)$ were calculated by installing a sensor with a

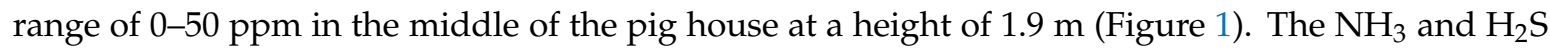
concentrations were determined using a sensoric- $\mathrm{NH}_{3} 3 \mathrm{E} 100 \mathrm{SE}$ (City Technology, Bonn, Germany) and using a $\mathrm{H}_{2} \mathrm{~S}-\mathrm{B} 4$ sensor (Alphasense Ltd., Great Notley, UK), respectively (Supplementary Figure S2).

\subsection{Growth Performance Measurement}

The pigs were weighed individually at the start and end of each period (weaning, growing, and finishing), and the body weight gain (BWG) was recorded. The feed intake (FI) was determined weekly by subtracting the remaining feed from the total feed offered, and the feed conversion ratio (FCR) was calculated.

\subsection{Statistical Analyses}

Statistical analyses were performed using the Statistical Analysis System (SAS, 2011, Version 9.3, Cary, NC, USA). The results are presented as the mean values and the standard error of the mean (SEM). All parameters in the groups were compared by an analysis of variance (ANOVA) and subsequent Duncan's multiple range test. The effects of the treatment were assessed using the following statistical model (Equation (3)).

$$
Y_{i j}=\mu+\alpha_{i}+e_{i j}
$$

where $\mu=$ general mean, $\alpha_{i j}=$ effect of treatment (GHP), $e_{i j}=$ random error, and $Y_{i j}=$ response variable. A value of $p<0.05$ was considered significant.

\section{Results and Discussion}

\subsection{Pig House Temperature and Relative Humidity}

Figure $4 \mathrm{a}-\mathrm{c}$ presents the overall distribution pattern of temperature for the control and GHP during each period (weaning, growing, and finishing). The relative humidity was calculated to be $50-60 \%$ during the entire experimental duration. The setting temperature was maintained at $26{ }^{\circ} \mathrm{C}$ during the first week of the weaning phase then gradually decreased at the rate of $1{ }^{\circ} \mathrm{C}$ per week until it reached $20^{\circ} \mathrm{C}$. The $20^{\circ} \mathrm{C}$ temperature was maintained until the end of the trial. The mean temperature during each period was significantly higher $(p<0.05)$ in the geothermal heating pig house 
than the outside temperature. The temperature during weaning was increased by $75 \%$ in the GHP system compared to the outside temperature and $7 \%$ relative to the control pig house temperature. Similarly, during the growing period, the temperature increased by $80 \%$ relative to the outside and $5 \%$ relative to the control pig house, while it increased by $83 \%$ and $2 \%$ compared to the outside and the control pig house temperature, respectively, during the finishing phase.

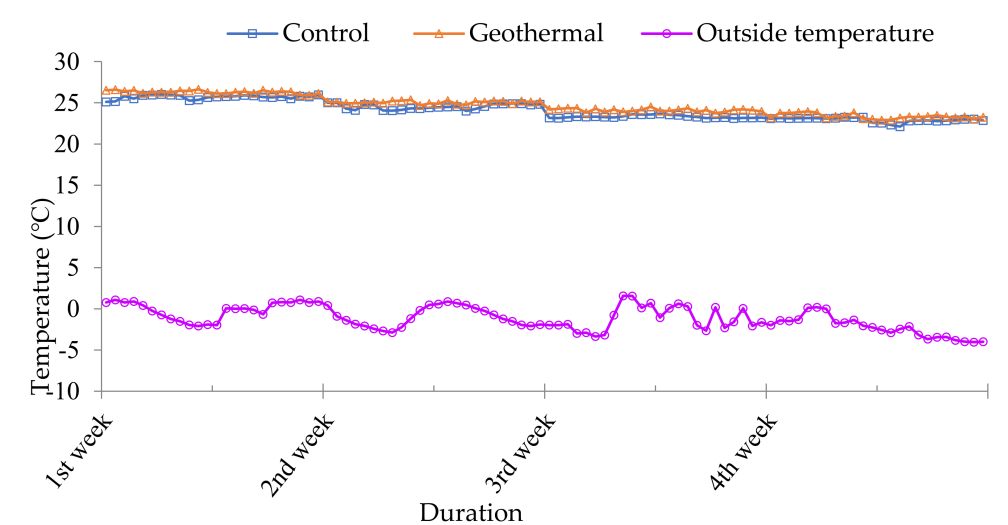

(a)

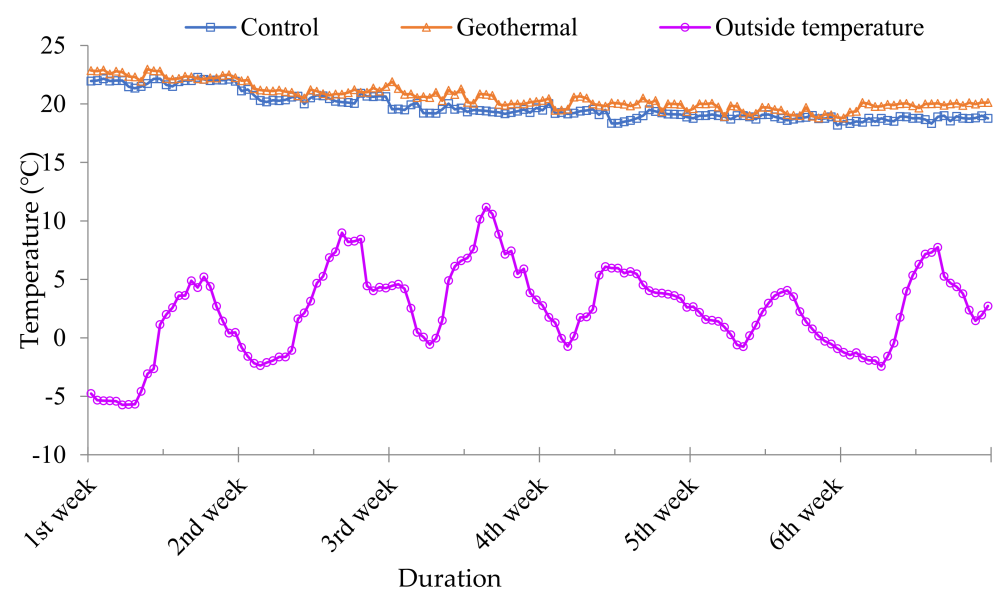

(b)

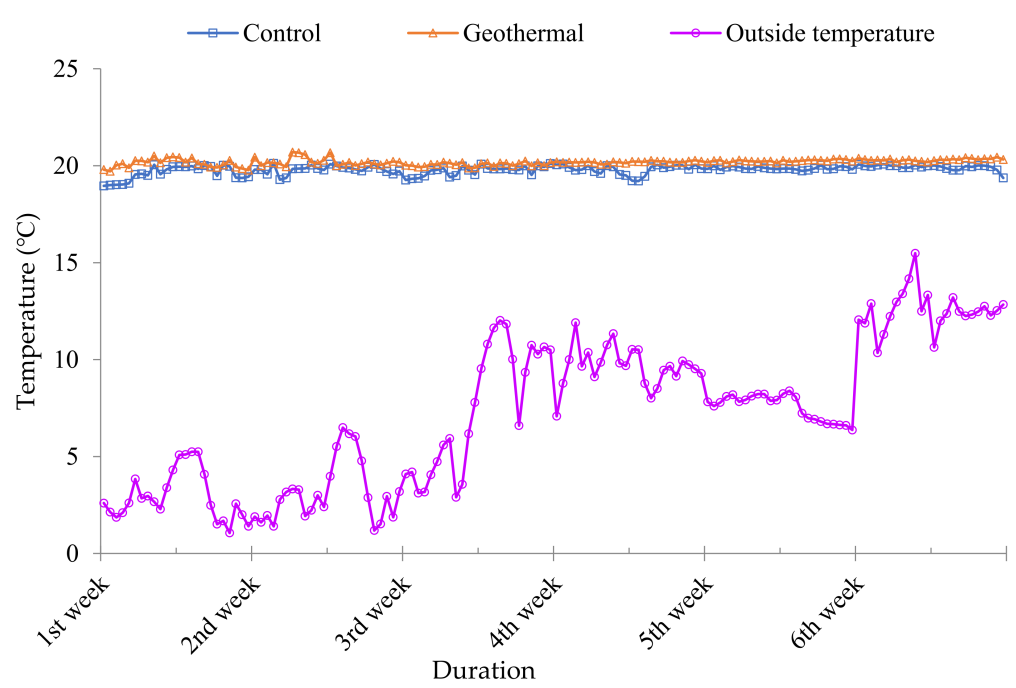

(c)

Figure 4. Temperature of the control pig house and geothermal heat pump connected pig house during the experiment. (a) Weaning period; (b) growing period; (c) finishing period. 
Environmental conditions can play an important role in pig production, and variation in these parameters may decrease the productivity of pigs. One of the challenging inside-room conditions for pig production is the ambient temperature, which is crucial to the efficiency of pig productivity and growth [20]. Various studies in different countries have reported the heating and cooling efficiency of GHP systems in winter and summer for pig fattening farms, farrowing houses, and broiler houses $[2,8,21]$. The increased pig house temperature in the GHP system might be due to the efficient heat conversion from groundwater and the uniform distribution by the FCU of the GHP system [8]. The results of the present study are also consistent with the findings of Omer et al. [22], who reported that a GHP could transfer adequate heat from the ground to the source via a hot water storage tank. Furthermore, GHP has a single-loop configuration, which is also called a direct heat exchange system, in which the working fluid of the heat pump passes through the ground heat exchanger and there is no need for a ground loop to heat the pump exchangers, which increases the heating efficiency of the system [22]. In short, a GHP can increase the pig house temperature in the severe cold season.

\subsection{Coefficient of Performance (COP) and Geothermal Systems Outlet and Inlet Temperature}

COP is an important parameter to evaluate the performance and heat efficiency of a heat pump. COP describes how much heat a GHP can generate with every watt of energy consumption [8]. The maximum and minimum COP calculated in this study was 4.10 and $4.50,4.15$ and 4.80, and 4.00 and 5.45 during the weaning, growing, and finishing periods, respectively (Table 2). The mean COP of the GHP system during the 16 weeks was 4.47. The calculated COP of the GHP system is close to the COP of 4.5 and 4.46 calculated for a geothermal heat pump system by Sanner et al. [23] and Islam et al. [8], respectively. The efficiency and performance index of the GHP system was evaluated using the COP. Usually, the COP of the ground source heat pump system (GSHP) ranges from 3.9 to 4.53 in summer and 4.19 to 4.57 in winter [24]. Moreover, GHPs (water-water type) are used widely in Korea owing to their better COP, as calculated in this study, and their ability for both cooling in summer and heating in winter [25].

Table 2. Coefficient of performance (COP) of the geothermal heat pump (GHP) during heating.

\begin{tabular}{|c|c|c|c|c|c|}
\hline \multirow{2}{*}{ Periods } & \multicolumn{2}{|c|}{ Heat Pump Water Flow Temperature $\left({ }^{\circ} \mathrm{C}\right)$} & \multirow{2}{*}{ Difference } & \multirow{2}{*}{ Heat Pump Consumption (kWh) } & \multirow{2}{*}{ COP } \\
\hline & Outflow & Inflow & & & \\
\hline \multicolumn{6}{|l|}{ Weaning } \\
\hline 1st week & 44.11 & 17.55 & 26.56 & 44.80 & 4.10 \\
\hline 2nd week & 44.22 & 14.96 & 29.26 & 44.20 & 4.46 \\
\hline 3rd week & 43.92 & 11.75 & 32.17 & 48.20 & 4.50 \\
\hline 4th week & 44.16 & 15.30 & 28.86 & 44.60 & 4.40 \\
\hline \multicolumn{6}{|l|}{ Growing } \\
\hline 1st week & 44.47 & 17.90 & 26.57 & 44.40 & 4.15 \\
\hline 2nd week & 44.15 & 16.60 & 27.55 & 39.70 & 4.64 \\
\hline 3rd week & 44.16 & 17.30 & 26.86 & 41.00 & 4.45 \\
\hline 4th week & 44.04 & 12.75 & 31.29 & 43.00 & 4.80 \\
\hline 5th week & 44.34 & 15.65 & 28.69 & 44.40 & 4.40 \\
\hline 6th week & 44.20 & 17.40 & 26.80 & 37.90 & 4.70 \\
\hline \multicolumn{6}{|l|}{ Finishing } \\
\hline 1st week & 44.50 & 18.30 & 26.20 & 43.10 & 4.20 \\
\hline 2nd week & 44.45 & 18.45 & 26.00 & 41.50 & 4.30 \\
\hline 3rd week & 44.15 & 18.65 & 25.50 & 45.50 & 4.00 \\
\hline 4th week & 43.85 & 18.92 & 24.93 & 29.40 & 5.45 \\
\hline 5th week & 44.04 & 19.00 & 25.04 & 36.50 & 4.60 \\
\hline 6th week & 44.05 & 17.90 & 26.15 & 37.50 & 4.65 \\
\hline Average & 44.00 & 16.75 & 27.25 & 44.50 & 4.47 \\
\hline
\end{tabular}

The inflow and outflow temperature of the water was examined at three points of the GHP system, including (1) from groundwater to heating pump and vice versa, (2) from heating pump to storage container and vice versa, and (3) from water storage to the pig house and vice versa (Figure 5a-c). The mean difference in the water outflow and inflow temperature was $0.27,28.90$, and $8.20{ }^{\circ} \mathrm{C}$ during 
the weaning phase; $0.25,27.50$, and 7.77 during the growing phase; and $0.20,25.70$, and 7.25 during the finishing phase for the groundwater to heating pump, heating pump to water reservoir, and water storage tank to the pig house, respectively $(p<0.05)$. The increased outflow temperature for the water storage tank and heat pump indicates the efficiency of the GHP system to convert energy to heat and provide sufficient heat to maintain the desired temperature of the pig house throughout the experiment.

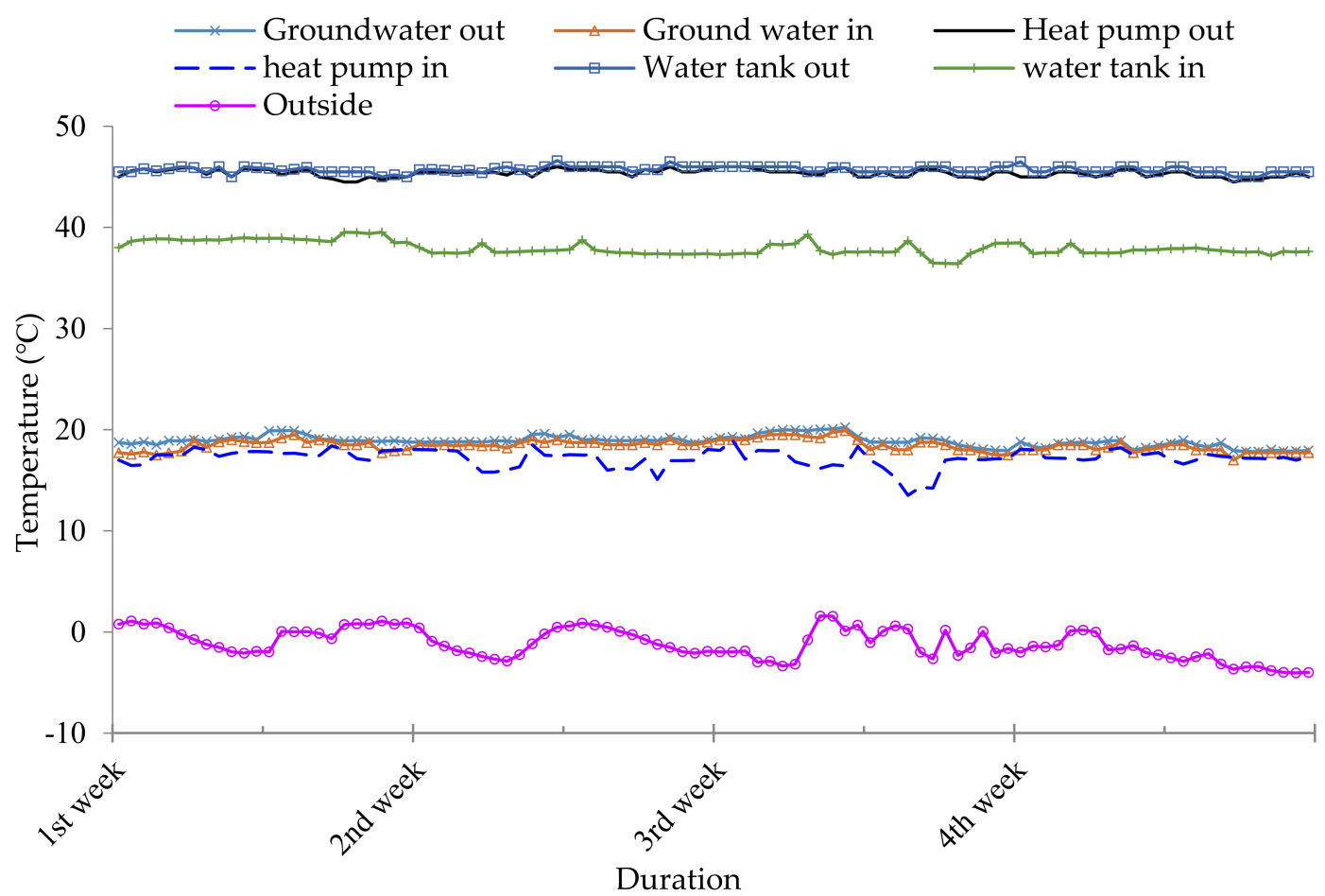

(a)

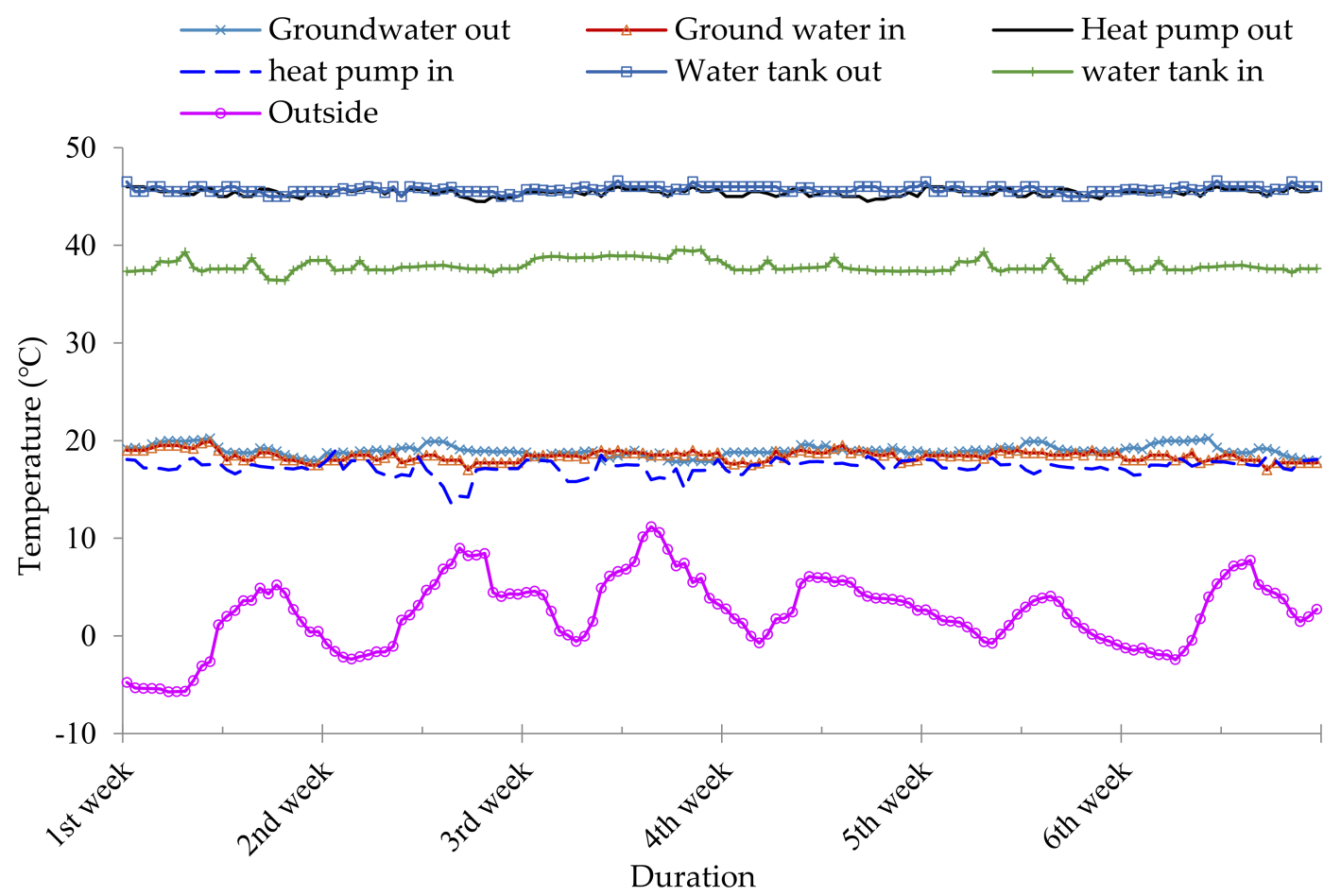

(b)

Figure 5. Cont. 


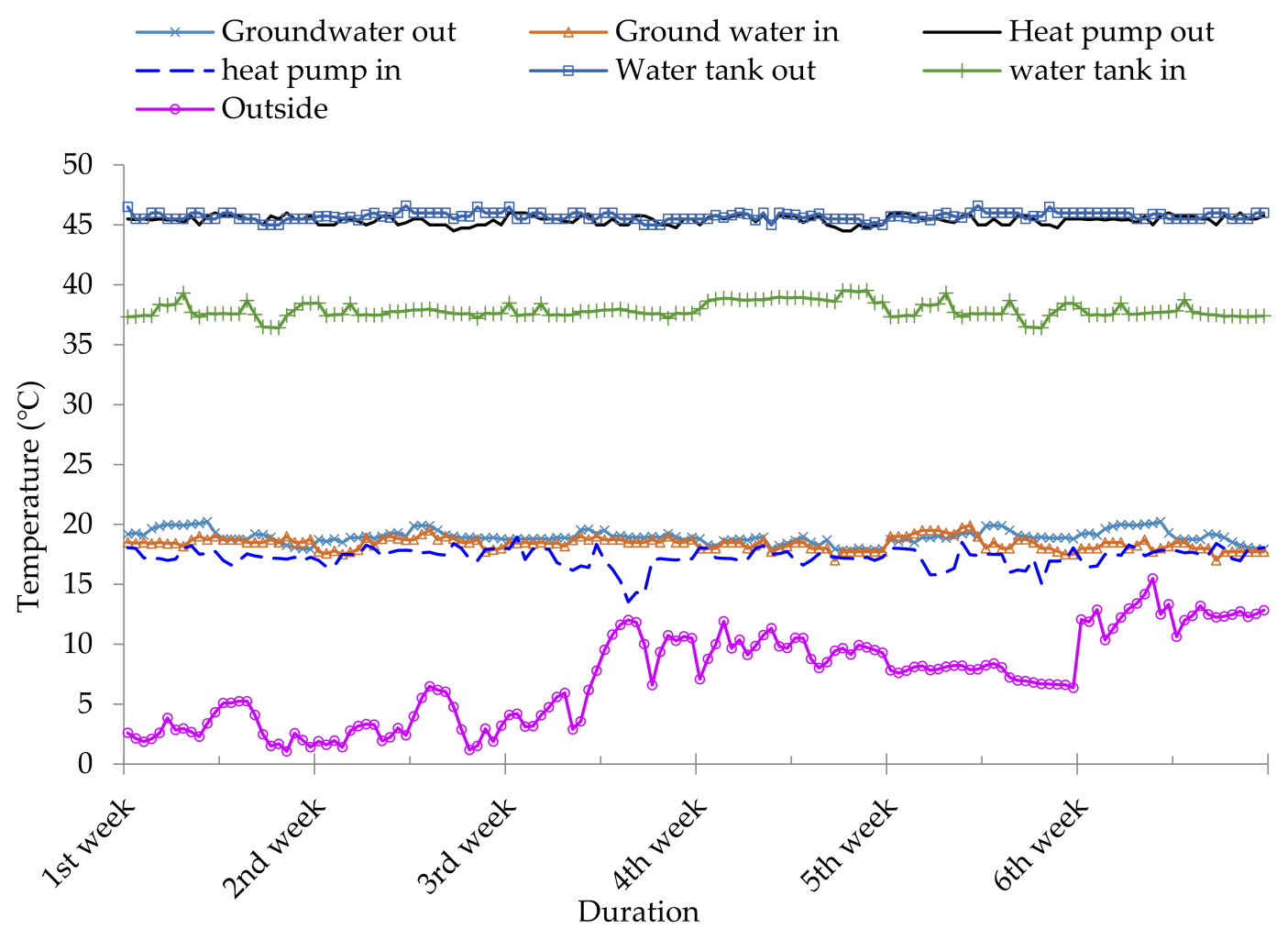

(c)

Figure 5. The inflow and outflow water temperature of three pumps of the geothermal system.

(a) Weaning period; (b) growing period; (c) finishing period.

\subsection{Formaldehyde, Ultrafine Dust $\left(\mathrm{PM}_{2.5}\right), \mathrm{NH}_{3}$, and $\mathrm{H}_{2} \mathrm{~S}$ Concentration}

The concentration of $\mathrm{H}_{2} \mathrm{~S}$ gas and $\mathrm{PM}_{2.5}$ in the pig house was unaffected $(p>0.05)$ by the heating system during the experimental period (Tables 3 and 4). On the other hand, $\mathrm{NH}_{3}$ concentrations were lowered significantly $(p<0.05)$ during the growing and finishing period in the GHP house compared to the control pig house (Table 2). Furthermore, the formaldehyde content was decreased significantly $(p<0.05)$ in the GHP house during the weaning period (Table 3).

Table 3. Effect of the geothermal heat pump (GHP) on ammonia $\left(\mathrm{NH}_{3}\right)$ and hydrogen sulfide $\left(\mathrm{H}_{2} \mathrm{~S}\right)$ concentrations in the pig house (ppm).

\begin{tabular}{ccccc}
\hline Items & Control & GHP & SEM $^{1}$ & $p$-Value \\
\hline \multicolumn{5}{c}{$\mathrm{NH}_{3}$ emission } \\
Weaning & 0.00 & 0.00 & 0.00 & - \\
Growing & $0.16^{\mathrm{a}}$ & $0.13^{\mathrm{b}}$ & 0.18 & $<0.0001$ \\
Finishing & $0.97^{\mathrm{a}}$ & $0.46^{\mathrm{b}}$ & 0.35 & $<0.0001$ \\
Average & $0.42^{\mathrm{a}}$ & $0.22^{\mathrm{b}}$ & 0.37 & $<0.0001$ \\
\hline \multicolumn{5}{c}{$\mathrm{H}_{2} \mathrm{~S}$ emission } \\
Weaning & 0.00 & 0.00 & 0.00 & - \\
Growing & 0.00 & 0.00 & 0.00 & - \\
Finishing & 5.14 & 5.35 & 0.45 & 0.9034 \\
Average & 1.93 & 2.01 & 0.67 & 0.9042 \\
\hline
\end{tabular}

a,b Values with different superscripts differ significantly. ${ }^{1}$ Standard error of the mean. 
Table 4. Effect of the geothermal heat pump (GHP) on formaldehyde (ppm) and ultrafine dust $\left(\mathrm{PM}_{2.5}\right)$ $\left(\mu \mathrm{g} / \mathrm{m}^{3}\right)$ in the pig house.

\begin{tabular}{ccccc}
\hline Items & Control & GHP & SEM $^{\mathbf{1}}$ & $p$-Value \\
\hline \multicolumn{5}{c}{ Formaldehyde } \\
Weaning & $0.06^{\mathrm{a}}$ & $0.04^{\mathrm{b}}$ & 0.03 & 0.0436 \\
Growing & 0.08 & 0.05 & 0.01 & 0.0649 \\
Finishing & 0.13 & 0.14 & 0.03 & 0.8146 \\
Average & 0.10 & 0.09 & 0.12 & 0.5955 \\
\hline \multicolumn{5}{c}{} \\
Weaning & 28.39 & 27.22 & 17.76 & 0.8242 \\
Growing & 29.03 & 27.48 & 28.83 & 0.7932 \\
Finishing & 21.14 & 21.20 & 14.72 & 0.9871 \\
Average & 25.84 & 25.00 & 19.31 & 0.7709 \\
\hline a,b Values with different superscripts differ significantly. ${ }^{1}$ Standard error of the mean.
\end{tabular}

The release of noxious gases from the animal houses, such as $\mathrm{NH}_{3}$ and $\mathrm{H}_{2} \mathrm{~S}$, has harmful effects on the animal health and production, environment, and health of workers staying at the farms [26]. The release of $\mathrm{NH}_{3}$ also depends on the climate conditions of the house, and concentration is positively correlated with the ventilation rate and ambient temperature [5]. Similarly, the concentrations of $\mathrm{PM}_{2.5}$ and formaldehyde from the pig house have adverse effects on the respiratory health of the animals and humans as well as a negative impact on the environment [27]. Misselbrook et al. [28] reported that the daily housing emission factor of 79.2 for fattening pigs per livestock unit (LU is equivalent to $500 \mathrm{~kg}$ live weight). Furthermore, Liu et al. [29] calculated that the median emission rates of $\mathrm{H}_{2} \mathrm{~S}$ and $\mathrm{NH}_{3}$ from pig houses were 0.09 and $2.78 \mathrm{~kg} / \mathrm{y}$, respectively. In the present study, there was an average $48 \%$ decrease in the concentration of $\mathrm{NH}_{3}$ from the GHP-equipped pig house compared to the control. The reason for the reduced $\mathrm{NH}_{3}$ concentration can be the improved air quality in the GHP pig house because GHP provides fresh air continuously and dilutes the $\mathrm{NH}_{3}$ inside the pig house [30]. The results of this experiment are consistent with Jacobson et al. [31], who reported that a GHP system reduced the concentration of $\mathrm{NH}_{3}$ by 20-30\% when heating the farrowing house. Pulat et al. [32] also described geothermal energy as a renewable and eco-friendly energy source that plays an important role in reducing global climate change, enhancing energy security, and protecting public health. On the other hand, a small amount of noncondensable gases, such as $\mathrm{CO}_{2}, \mathrm{NH}_{3}, \mathrm{H}_{2} \mathrm{~S}$, methane $\left(\mathrm{CH}_{4}\right)$, and nitrogen $\left(\mathrm{N}_{2}\right)$, may be emitted through the GHP system, which is harmless to the animals and workers [33].

Ultrafine dust has become an emerging major public health concern in South Korea. $\mathrm{PM}_{2.5}$ can penetrate the lungs, placental barrier, and blood-brain barrier [34]. Although no significant differences in the levels of ultrafine dust were observed between the control and GHP system, the values of $\mathrm{PM}_{2.5}$ were in accordance with the standards of national ambient air quality standards (AQS) in Korea. The AQS of $\mathrm{PM}_{2.5}$ was $50 \mu \mathrm{g} / \mathrm{m}^{3}$ for $24 \mathrm{~h}$ [34]. Formaldehyde is an eye and skin irritant and is also classified as a carcinogenic agent. One of the primary sources of formaldehyde emission into the environment is heating systems and waste incinerators [35]. The GHP system reduced the concentration of formaldehyde significantly in the weaning phase, which requires more heating compared to other periods of pig production. Formaldehyde at concentrations of $0.10-0.11 \mathrm{ppm}$ cause symptoms in both animals and humans [35]. In the present study, the average formaldehyde level in the GHP pig house was in the acceptable range as recommended.

\subsection{Electricity Consumption, $\mathrm{CO}_{2}$ Concentration, and Cost}

Table 5 lists the electricity consumption and $\mathrm{CO}_{2}$ concentration of the GHP-installed and conventional electricity-heated pig house. During the entire experimental trial, the electricity consumption by the GHP system was 38\% lower (by $2743 \mathrm{kWh}$ ) than the conventional system. This might be caused by the efficient and uniform heat distribution by the GHP system because of its 
high COP and fewer operating hours. Charoenvisal [12] also reported that GHP could supply three units of electricity per unit consumption, which can eventually decrease the consumption of electricity.

Table 5. Effect of the geothermal heat pump (GHP) on electricity consumption $(\mathrm{kWh})$ and $\mathrm{CO}_{2}$ concentration $(\mathrm{kg})$ in the pig house for 16 weeks.

\begin{tabular}{|c|c|c|c|c|c|c|}
\hline \multirow{2}{*}{ Periods } & \multicolumn{2}{|c|}{ Electricity Use } & \multirow{2}{*}{ Reduced } & \multicolumn{2}{|c|}{$\mathrm{CO}_{2}$ Emission } & \multirow{2}{*}{ Reduced } \\
\hline & Control & GHP & & Control & GHP & \\
\hline Weaning & $3053^{a}$ & $1565^{b}$ & 1488 & $1670^{a}$ & $856^{\mathrm{b}}$ & 814 \\
\hline Growing & $2524^{\mathrm{a}}$ & $2035^{b}$ & 507 & $1390^{a}$ & $1113^{b}$ & 277 \\
\hline Finishing & $1467^{\mathrm{a}}$ & $719^{b}$ & 748 & $803^{a}$ & $393^{b}$ & 410 \\
\hline Total & $7062^{a}$ & $4319^{b}$ & 2743 & $3863^{a}$ & $2362^{b}$ & 1501 \\
\hline
\end{tabular}

Electricity production comprises the second-largest percentage (26.9\%) of greenhouse gas emissions (GHE), which leads to a range of health and environmental effects [36]. Therefore, there is a high demand for alternative energy sources to reduce environmental pollution. In the present study, $\mathrm{CO}_{2}$ emissions were reduced significantly (by $1501 \mathrm{~kg}$ ) in the GHP system relative to the control. GHP can decrease the GHE substantially, which is important for not only the environment but also for the well-being of workers and animals [31]. In support of these findings, many scientists $[8,17,19]$ have reported that $\mathrm{CO}_{2}$ concentration and energy consumption were reduced by installing GHP systems for heating buildings and animal farms because of their energy efficiency.

Figure 6 shows the heating cost of the GHP-supported pig house and the control. The electricity expenditure for the GHP system was reduced significantly (by $40 \%$ ) compared to the conventional heating system. Similarly, Barbier et al. [17] reported a decrease in the cost of electricity using a GHP for heating industrial and agricultural facilities. GHP systems use a renewable energy source, whereas conventional heating uses the combustion of fuels to generate electricity and heating. This might explain the low electricity cost in a GHP-installed pig house. The cost of heating pig houses is one of the major challenges for pig farmers because the price of fuel and electricity is increasing continuously in Korea and throughout the world. In the present study, GHP was more economical than the control under severe weather conditions. Moreover, the energy produced by the GHP decreased the GHE concentration in the environment, which finally decreased environmental pollution [15]. Therefore, the ground source geothermal heat pump is an effective renewable, alternative, and environmentally friendly energy source in Korea.

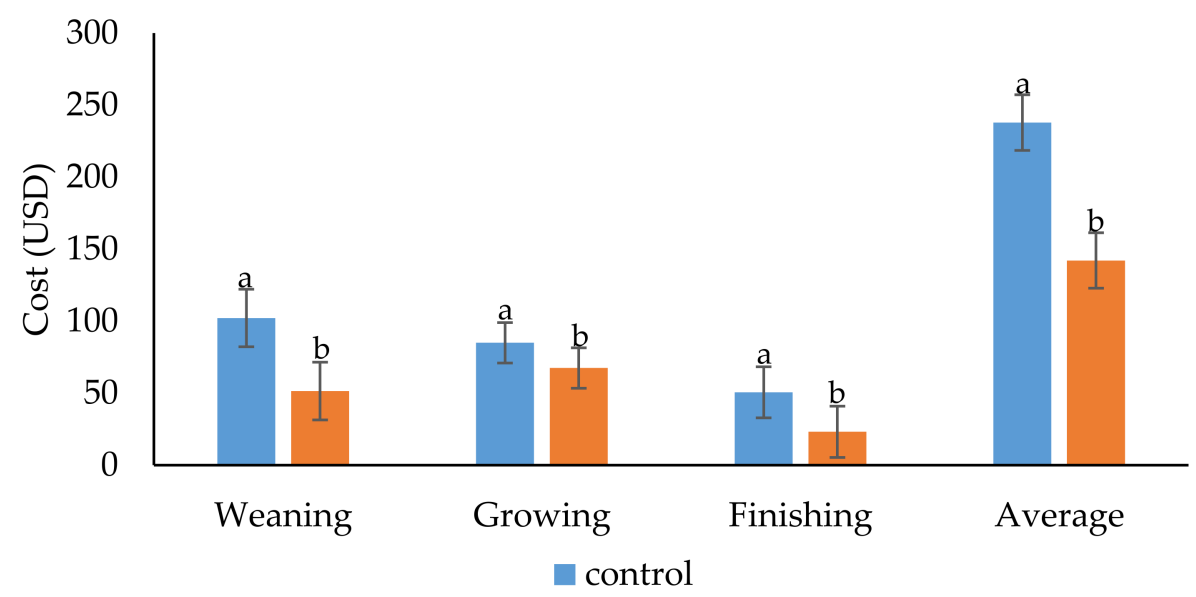

Figure 6. The effect of the geothermal heat pump (GHP) on the cost of electricity during the weaning, growing, and finishing period. $a, b$ Bars at a particular point with different alphabet differ significantly $(p<0.05)$. 


\subsection{Production Performance Parameters}

Table 6 lists the effects of the GHP on the production performance parameters of pigs. The BWG, FI, and FCR did not differ $(p>0.05)$ between the control and GHP-equipped pig house.

Table 6. Effect of the geothermal heat pump (GHP) on production performance parameters.

\begin{tabular}{ccccc}
\hline Item & Control & GHP & SEM & $p$-Value \\
\hline \multicolumn{5}{c}{ Weaning period $(0-4$ weeks) } \\
Initial weight $(\mathrm{kg})$ & 8.56 & 8.89 & 2.87 & 0.8158 \\
Final weight $(\mathrm{kg})$ & 25.81 & 26.81 & 4.48 & 0.6506 \\
Weight gain $(\mathrm{kg})$ & 17.26 & 17.92 & 2.38 & 0.5627 \\
Feed intake $(\mathrm{kg})$ & 33.48 & 36.09 & 6.19 & 0.3945 \\
FCR (feed/gain) & 1.95 & 2.03 & 0.37 & 0.6448 \\
\hline \multicolumn{5}{c}{ Growing period $(4-10$ weeks) } \\
Initial weight $(\mathrm{kg})$ & 25.81 & 26.81 & 4.48 & 0.6506 \\
Final weight $(\mathrm{kg})$ & 70.77 & 68.53 & 5.47 & 0.4313 \\
Weight gain $(\mathrm{kg})$ & 44.96 & 41.72 & 3.29 & 0.0726 \\
Feed intake $(\mathrm{kg})$ & 100.93 & 105.44 & 14.59 & 0.5216 \\
FCR (feed/gain) & 2.25 & 2.53 & 0.33 & 0.0975 \\
\hline \multicolumn{5}{c}{ Finishing period $(10-16$ weeks) } \\
Initial weight $(\mathrm{kg})$ & 70.77 & 68.53 & 5.47 & 0.4313 \\
Final weight $(\mathrm{kg})$ & 113.43 & 108.59 & 7.24 & 0.1801 \\
Weight gain $(\mathrm{kg})$ & 42.66 & 40.06 & 4.39 & 0.2449 \\
Feed intake $(\mathrm{kg})$ & 150.81 & 143.46 & 21.28 & 0.4801 \\
FCR (feed/gain) & 3.53 & 3.58 & 0.32 & 0.7533 \\
\hline \multicolumn{5}{c}{ Average period (0-16 weeks) } \\
Initial weight $(\mathrm{kg})$ & 8.56 & 8.89 & 2.87 & 0.8158 \\
Final weight $(\mathrm{kg})$ & 113.43 & 108.59 & 7.24 & 0.1801 \\
Weight gain $(\mathrm{kg})$ & 104.88 & 99.70 & 1.83 & 0.0900 \\
Feed intake $(\mathrm{kg})$ & 285.23 & 284.99 & 11.34 & 0.9895 \\
FCR (feed/gain) & 2.71 & 2.85 & 0.08 & 0.2686 \\
\hline
\end{tabular}

${ }^{1}$ Standard error of the mean.

Growth performance parameters, such as the market weight and FCR, are important economic parameters for swine farmers in pig production [37]. These attributes must be considered first before any technology can be introduced in pig farming. In the present study, the GHP system had no negative effect on pig performance compared to the conventional heating system. These results are in agreement with Choi et al. [16], who reported that the geothermal heating pump system (GHPS) did not affect the BWG and FI in the farrowing house. Moreover, the production performance is a multifactorial dependent parameter that not only depends on the environmental conditions but also the management, feed, disease incidence, and genetic potential [38].

\subsection{Annual Operational and Initial Installation Cost}

Table 7 lists the initial installation and operational cost for the GHP and conventional system. Despite the higher initial investment for the GHP system, the operational expense was $50 \%$ lower than the conventional system because of energy efficiency and a higher COP. In the present study, GHP was installed at a research farm, which is relatively smaller than the commercial pig farm. Therefore, the operational cost and profit margin may be improved further at a commercial farm. As a result of rapid economic development, many countries are facing a huge challenge in energy shortage, environmental pollution, and climate change. Energy shortage is one of the most serious problems, and renewable energy reduces the dependence of food production on fossil fuels as well as decreases GHE. Therefore, the combination of food production with renewable energy would be a prosperous implementation to increase food security by enhancing production at a lower cost [39]. 
Table 7. Operational and installation cost of the geothermal heat pump (GHP) and a conventional heating system.

\begin{tabular}{|c|c|c|c|}
\hline & Conventional Heating & GHP & \\
\hline Installation cost (USD) & 4420 & 17,676 & \multirow{4}{*}{$\begin{array}{l}\text { According to the } \\
\text { manufacturer's instruction }\end{array}$} \\
\hline Life span & Up to 5 years & $\begin{array}{l}\text { (1) Ground loop, } 50 \text { years } \\
\text { (2) Heat pump, } 25 \text { years }\end{array}$ & \\
\hline Operational cost annually ${ }^{1}$ (USD) & 713.52 & 426.12 & \\
\hline Depreciation time & 5 years & 25 years & \\
\hline
\end{tabular}

${ }^{1}$ Annual operational cost was calculated based on the yearly electricity consumption and local unit price.

Thus, the GHP system is likely to be accepted in the future considering the heating effect, energy-saving, welfare and health of animals and workers, and environmental pollution. On the other hand, the assistance of governments through subsidies will be necessary to broaden the installation of GHP systems to animal farms for energy-saving and protecting the environment [40].

\section{Conclusions}

The GHP system reduced energy consumption and electricity cost during the experimental period. The $\mathrm{CO}_{2}$ emission and noxious gas $\left(\mathrm{NH}_{3}\right.$ and formaldehyde) emissions were also reduced in the GHP-installed pig house. Despite the high initial installation cost, pig producers could benefit in the long term in commercial production with lower operational costs and reduced environmental pollution. Therefore, the GHP system might be a more effective sustainable renewable energy source in the future for pig performance and welfare, cost-saving, and mitigating environmental pollution.

Supplementary Materials: The following are available online at http://www.mdpi.com/2076-2615/10/11/2075/s1, Figure S1: A geothermal heat pump system, Figure S2: NR-TH set for temperature and humidity detection. Sensors for determination of $\mathrm{NH}_{3}$ and $\mathrm{H}_{2} \mathrm{~S}$ emission, Figure S3: Smart sensor air quality meter, Table S1: Specifications of geothermal heat pump, Table S2: Specifications of exhaust fans in pig house.

Author Contributions: Conceptualization, H.S.M., K.W.P., S.R.L. and, C.J.Y.; methodology, H.S.M., M.A.D., M.G.J., D.R., J.S.W., K.W.P., S.R.L. and S.B.R.; software, H.S.M., M.A.D., M.G.J. and S.B.R.; validation, H.S.M., M.A.D. and C.J.Y.; formal analysis, H.S.M., M.A.D., M.G.J., D.R., J.S.W., K.W.P., S.R.L. and S.B.R.; investigation, H.S.M., M.A.D., M.G.J., D.R., J.S.W., K.W.P., S.R.L. and S.B.R.; resources, K.W.P., S.R.L. and C.J.Y.; data curation, H.S.M., M.A.D., M.G.J., D.R. and J.S.W.; writing—original draft preparation, M.A.D.; writing-review and editing, H.S.M., M.A.D. and C.J.Y.; visualization, H.S.M., M.A.D., M.G.J., D.R. and J.S.W.; supervision, H.S.M., J.S.W., K.W.P. and C.J.Y.; project administration, H.S.M., J.S.W., K.W.P. and C.J.Y.; funding acquisition, J.S.W., K.W.P. and C.J.Y. All authors have read and agreed to the published version of the manuscript.

Funding: This research was supported and funded by the Industrial Technology Innovation Business (20194210100020, Development and Demonstration of Renewable Energy Mixed-Use System for the Livestock Industry), the Ministry of Trade, Industry and Energy, Korea.

Conflicts of Interest: The authors declare no conflicts of interest.

\section{Nomenclature}

$\begin{array}{ll}\text { ANOVA } & \text { Analysis of variance } \\ \text { AQS } & \text { Ambient air quality standards } \\ \text { BHE } & \text { Borehole exchanger } \\ \text { BWG } & \text { Body weight gain } \\ \mathrm{CH}_{4} & \text { Methane } \\ \mathrm{COP} & \text { Coefficient of performance } \\ \mathrm{CO}_{2} & \text { Carbon dioxide } \\ \mathrm{C}_{\mathrm{p}} & \text { Specific heat }\left(\mathrm{kcal} / \mathrm{kg}^{\circ} \mathrm{C}\right) \\ \text { FA } & \text { Formaldehyde } \\ \text { FCR } & \text { Feed conversion ratio } \\ \text { FCU } & \text { Fan coil unit } \\ \text { FI } & \text { Feed intake } \\ \text { GER } & \text { Geothermal energy resources }\end{array}$




$\begin{array}{ll}\text { GHP } & \text { Geothermal heat pump } \\ \text { HPU } & \text { Heating pump unit } \\ \mathrm{H}_{2} \mathrm{~S} & \text { Hydrogen sulfide } \\ \mathrm{KRW} & \text { Korean won } \\ \mathrm{kW} & \text { Kilowatt } \\ \mathrm{kWh} & \text { kilowatt-hour } \\ \mathrm{M} & \text { mass flow rate }(\mathrm{kg} / \mathrm{h}) \\ \mathrm{m} & \text { meters } \\ \mathrm{NH}_{3} & \text { Ammonia } \\ \mathrm{N}_{2} & \text { Nitrogen } \\ \mathrm{PM}_{2.5} & \text { Particulate matter } \\ \mathrm{SEM} & \text { Standard error of the mean } \\ \Delta \mathrm{T} & \text { Inlet-outlet temperature difference }\left({ }^{\circ} \mathrm{C}\right) \\ \mu & \text { General mean } \\ \alpha_{\mathrm{ij}} & \text { Effect of treatment } \\ \mathrm{e}_{\mathrm{ij}} & \text { Random error } \\ \mathrm{Y}_{\mathrm{ij}} & \text { Response variable }\end{array}$

\section{References}

1. Riva, G.; Pedretti, E.F.; Fabbri, C. Utilization of a heat pump in pig breeding for energy saving and climate and ammonia control. J. Agric. Eng. Res. 2000, 77, 449-455. [CrossRef]

2. Choi, H.C.; Salim, H.M.; Akter, N.; Na, J.C.; Kang, H.K.; Kim, M.J.; Kim, D.W.; Bang, H.T.; Chae, H.S.; Suh, O.S. Effect of heating system using a geothermal heat pump on the production performance and housing environment of broiler chickens. Poult. Sci. 2012, 91, 275-281. [CrossRef] [PubMed]

3. Fabbri, C.; Valli, L.; Guarino, M.; Costa, A.; Mazzotta, V. Ammonia, methane, nitrous oxide and particulate matter emissions from two different buildings for laying hens. Biosyst. Eng. 2007, 97, 441-455. [CrossRef]

4. Rodriguez, M.R.; Losada, E.; Besteiro, R.; Arango, T.; Velo, R.; Ortega, J.A.; Fernandez, M.D. Evolution of $\mathrm{NH}_{3}$ concentrations in weaner Pig buildings based on set point Temperature. Agronomy 2020, 10, 107. [CrossRef]

5. Philippe, F.-X.; Cabaraux, J.-F.; Nicks, B. Ammonia emissions from pig houses: Influencing factors and mitigation techniques. Agric. Ecosyst. Environ. 2011, 141, 245-260. [CrossRef]

6. Galloway, J.N.; Dentener, F.J.; Capone, D.G.; Boyer, E.W.; Howarth, R.W.; Seitzinger, S.P.; Asner, G.P.; Cleveland, C.C.; Green, P.A.; Holland, E.A.; et al. Nitrogen cycles: Past, present, and future. Biogeochemistry 2004, 70, 153-226. [CrossRef]

7. Bilen, K.; Ozyurt, O.; Bakırc1, K.; Karslı, S.; Erdogan, S.; Yılmaz, M.; Comakli, O. Energy production, consumption, and environmental pollution for sustainable development: A case study in Turkey. Renew. Sustain. Energy Rev. 2008, 12, 1529-1561. [CrossRef]

8. Islam, M.M.; Mun, H.-S.; Bostami, A.B.M.R.; Ahmed, S.T.; Park, K.-J.; Yang, C.-J. Evaluation of a ground source geothermal heat pump to save energy and reduce $\mathrm{CO}_{2}$ and noxious gas emissions in a pig house. Energy Build. 2016, 111, 446-454. [CrossRef]

9. Lund, J.W.; Freeston, D.H.; Boyd, T.L. Direct application of geothermal energy: 2005 worldwide review. Geothermics 2005, 34, 691-727. [CrossRef]

10. Potočnik, J. Renewable energy sources and the realities of setting an energy agenda. Science 2007, 315, 810-811. [CrossRef]

11. Alberti, L.; Antelmi, M.; Angelotti, A.; Formentin, G. Geothermal heat pumps for sustainable farm climatization and field irrigation. Agric. Water Manag. 2018, 195, 187-200. [CrossRef]

12. Charoenvisal, K. Energy Performance and Economic Evaluations of the Geothermal Heat Pump System Used in the Knowledge Works I and II Buildings, Blacksburg, Virginia. Master's Thesis, Virginia Polytechnic Institute and State University, Blacksburg, VA, USA, 2008.

13. Benli, H.; Durmuş, A. Evaluation of ground-source heat pump combined latent heat storage system performance in greenhouse heating. Energy Build. 2009, 41, 220-228. [CrossRef]

14. Hepbasli, A. Thermodynamic analysis of a ground-source heat pump system for district heating. Int. J. Energy Res. 2005, 29, 671-687. [CrossRef] 
15. Lee, Y.; Park, S.; Kim, J.; Kim, H.C.; Koo, M.-H. Geothermal resource assessment in Korea. Renew. Sustain. Energy Rev. 2010, 14, 2392-2400. [CrossRef]

16. Choi, H.C.; Park, J.H.; Song, J.I.; Na, J.C.; Kim, M.J.; Bang, H.T.; Kang, H.J.; Park, S.B.; Chae, H.S.; Suh, O.S.; et al. Evaluation on heating effects of Geothermal Heat Pump system in farrowing house. J. Livest. Hous. Environ. 2010, 16, 205-215.

17. Barbier, E. Geothermal energy technology and current status: An overview. Renew. Sustain. Energy Rev. 2002, 6, 3-65. [CrossRef]

18. Rybach, L. Geothermal energy: Sustainability and the environment. Geothermics 2003, 32, 463-470. [CrossRef]

19. Sebarchievici, C.; Sarbu, I. Performance of an experimental ground-coupled heat pump system for heating, cooling and domestic hot-water operation. Renew. Energy 2015, 76, 148-159. [CrossRef]

20. Hessel, E.F.; Zurhake, C. Heating and cooling performance of an under floor earth tube air tempering system in a mechanical ventilated farrowing house. In Proceedings of the XVII World congress of the International Commission of Agricultural and Bio Systems Engineering (CIGR), Québec City, QC, Canada, 13-17 June 2010.

21. Licharz, H.; Rösmann, P.; Krommweh, M.S.; Mostafa, E.; Büscher, W. Energy Efficiency of a Heat Pump System: Case Study in Two Pig Houses. Energies 2020, 13, 662. [CrossRef]

22. Mustafa Omer, A. Ground-source heat pumps systems and applications. Renew. Sustain. Energy Rev. 2008, 12, 344-371. [CrossRef]

23. Sanner, B.; Karytsas, C.; Mendrinos, D.; Rybach, L. Current status of ground source heat pumps and underground thermal energy storage in Europe. Geothermics 2003, 32, 579-588. [CrossRef]

24. Man, Y.; Yang, H.; Wang, J.; Fang, Z. In situ operation performance test of ground coupled heat pump system for cooling and heating provision in temperate zone. Appl. Energy 2012, 97, 913-920. [CrossRef]

25. Aikins, K.A.; Choi, J.M. Current status of the performance of GSHP (ground source heat pump) units in the Republic of Korea. Energy 2012, 47, 77-82. [CrossRef]

26. Dilawar, M.A.; Saturno, J.F.L.; Mun, H.-S.; Kim, D.-H.; Jeong, M.-G.; Yang, C.-J. Influence of two plant extracts on broiler performance, oxidative stability of meat and odorous gas emissions from excreta. Ann. Anim. Sci. 2019, 19, 1099-1113. [CrossRef]

27. Cambra-López, M.; Hermosilla, T.; Lai, H.T.L.; Aarnink, A.J.A.; Ogink, N.W.M. Particulate Matter Emitted from Poultry and Pig Houses: Source Identification and Quantification. Trans. ASABE 2011, 54, 629-642. [CrossRef]

28. Misselbrook, T.H.; Van der Weerden, T.J.; Pain, B.F.; Jarvis, S.C.; Chambers, B.J.; Smith, K.A.; Phillips, V.R.; Demmers, T.G.M. Ammonia emission factors for UK agriculture. Atmos. Environ. 2000, 34, 871-880. [CrossRef]

29. Liu, Z.; Powers, W.; Murphy, J.; Maghirang, R. Ammonia and hydrogen sulfide emissions from swine production facilities in North America: A meta-analysis. J. Anim. Sci. 2014, 92, 1656-1665. [CrossRef]

30. Choi, H.; Song, J.; Na, J.; Kim, M.; Bang, H.; Kang, H.; Park, S.; Chae, H.; Suh, O.; Yoo, Y. Evaluation on cooling effects of geothermal heat pump system in farrowing house. J. Livest. Hous. Environ. 2010, 16, 99-108.

31. Jacobson, L.D. Pig Housing Systems Designed to Manage or Adapt to Climate Change Impacts. In Proceedings of the Allen D. Leman Swine Conference, St. Paul, MI, USA, 15-18 September 2012.

32. Pulat, E.; Coskun, S.; Unlu, K.; Yamankaradeniz, N. Experimental study of horizontal ground source heat pump performance for mild climate in Turkey. Energy 2009, 34, 1284-1295. [CrossRef]

33. Holm, A.; Jennejohn, D.; Blodgett, L. Geothermal Energy and Greenhouse Gas Emissions. Geothermal Energy Association, 2012. Available online: http://geoenergy.org/reports/GeothermalGreenhouseEmissionsNov2012G EAweb.pdf (accessed on 23 July 2015).

34. Kang, D.; Kim, J.-E. Fine, ultrafine, and yellow dust: Emerging health problems in Korea. J. Korean Med. Sci. 2014, 29, 621-622. [CrossRef]

35. Subasi, N.T. Formaldehyde advantages and disadvantages: Usage Areas and Harmful Effects on Human Beings. In Biochemical Toxicology-Heavy Materials and Nanomaterials; Ince, M., Kaplan Ince, O., Ondrasek, G., Eds.; IntechOpen: London, UK, 2020.

36. EPA-United States Environment protection Agency. Sources of Greenhouse Gas Emissions. Available online: https://www.epa.gov/ghgemissions/sources-greenhouse-gas-emissions (accessed on 1 September 2020).

37. Kim, Y.S.; Kim, S.W.; Weaver, M.A.; Lee, C.Y. Increasing the Pig Market Weight: World Trends, Expected Consequences and Practical Considerations. Asian-Australas. J. Anim. Sci. 2005, 18, 590-600. [CrossRef] 
38. Murihead, M.R.; Alexander, T.J. Managing Pig Health: A Reference for the Farm, 2nd ed.; 5m Publishing: Sheffield, UK, 2013.

39. Keren Kayemeth leIsrael Jewish National Fund. Food Security and Renewable Energy News. Available online: https://www.kkl-jnf.org/research-and-development/food-security-renewable-energy/ (accessed on 1 October 2020).

40. Wang, M.Z.; Wu, Z.H.; Chen, Z.H.; Tian, J.H.; Liu, J.J. Economic Performance Study on the Application of Ground Source Heat Pump System in Swine Farms in Beijing China. AASRI Procedia 2012, 2, 8-13. [CrossRef]

Publisher's Note: MDPI stays neutral with regard to jurisdictional claims in published maps and institutional affiliations.

(C) 2020 by the authors. Licensee MDPI, Basel, Switzerland. This article is an open access article distributed under the terms and conditions of the Creative Commons Attribution (CC BY) license (http://creativecommons.org/licenses/by/4.0/). 